\title{
An Overview on Pros \& Cons of Business Method Patents (BMPs)
}

\author{
Associate Prof. Dr. Nazura Abdul Manap \\ Faculty of Law, University KebangsaanMalaysia(UKM), nazura@ukm.my
}

\section{Maryam Rafiei}

PhD Candidate, Faculty of Law, University Kebangsaan Malaysia,(UKM),Maria.rafiei@yahoo.com

\author{
Doi:10.5901/mjss.2016.v7n4p
}

\section{Abstract}

Of late, there has been a gradual shift in how the courts treat the issue of patentable subject matters and its exceptions in judicial systems. The biggest challenge in patent laws is to strike a balance between protecting inventors and preventing the creation of monopolies that would frustrate innovation and invention. Where the balance should stand is not the issue guiding such legal opinions. Patents essentially should further the basic economic ends of efficiently allocating resources, and how much business methods have been fostered by this and whether patents on such methods should be accepted or rejected are the subject of much debate. In fact the various opinions on the patentability of business method programs have remained unclear among judicial systems. This study examines the patentability of business methods by discussing the various pros and cons opinions. The main objective of this study is to clarify the various positions by previous authors in line with the BMPS and lead it to advance the position that there is a need to provide patent protection to business methods and their inventors.

Keywords: Business Method Patents, Computer Program Patents, Invention.

\section{Introduction}

Patents are a means of protecting inventions and legally allow inventors to apply for and obtain the right to exclude others from making, using, or selling them based on certain criteria such as prescribing the parameters that define the product. Just as a deed defines the boundaries of a land in determining if trespass has occurred, a patent will establish if there is a breach in its claims. As such it is important to prescribe a legal, time-limited monopoly on an invention that is specified in the claims on an issued patent.(Thiele, Blakeway \& Hosch, 2010).

A unique judicial precedent that departs significantly from the traditional approach has contributed to the large increase in the number of computer program applications being granted patent protection towards the end of the last century and the attendant controversy over those numbers in the last decade.(Duffy,2011) The huge impact of computer technology and issues of patent protection on modern life is undeniable. In this regard, whether Business Method Programs (BMP) can be considered patentable inventions remains highly contentious and much debated among the legal and judicial fraternity across the globe. The issues revolve not so much around whether business methods should be patentable but more on the various approaches taken by the law and courts on their relevance to all applications. Views on the issue are diametrically opposed to one another. In the US, judicial decisions that seek to provide broad interpretations on the law do not help in achieving legal clarity although they have shown a slight flexibility to these patents.

The rapid spread and advancements in technology has had a significant impact on everyday life. As such, it is important that temporary monopoly rights and safeguards are instituted to protect the inventors of such creations and how they operate from being used by others for their own gain. ${ }^{1}$ This also prevents others from building upon an idea or invention to secure benefits that should rightly be attributed to the original inventor. In this regard, the role of the courts is important in establishing whether the invention is rightful and useful and deserves to have patent protection.

While there have been many opinions and theories on the merits or otherwise of the patent system, fears or concerns about it are not backed by evidence. According to (Machlup, 1958), "If we did not have a patent system, it would be irresponsible, on the basis of our present knowledge of its economic consequences, to recommend instituting one. But since we have had a patent system for a long time, it would be irresponsible, on the basis of our present knowledge, to

\footnotetext{
1 Sometimes for 20 years as it is in the US or 17 years as in the EU.
} 
recommend abolishing it."

A major issue is how to protect computer programs in the form of business methods or other types of programs from being copied. The rapid advancements in technology, innovations, and inventions have highlighted the strength and rapidly expanding link between computers and business on the one hand and the general public on the other, especially with the increasing reliance on computers in everyday applications.(Durell, 2000).

Using various opinions and perspectives, this paper focuses on whether BMPs are patentable rather than on whether existing patent law systems and laws can be used to address inherent quality issues. It seeks to determine the position of business methods as determined by the views of other authors and researchers.

\section{Research Methodology}

The literature and perspectives on the obstacles to and basis for patenting BMPs are prolific. Such opinions and perspectives are covered in various text books, journals, articles, and court decisions. This paper is based on library research using both primary and secondary sources. The data for this research is based on readings of the literature, acts, regulations and various research theses. This methodology method was taken in order to ease the way of getting information regarding BMPs. Accessing to reliable data in this field was possible via library study which means by using books, articles, regulations and rules as well as reviewing the previous literature. In addition information is also sourced electronically via legal websites such as Lexis Nexis, CLJ Law, Social Science, Google Scholar, Google Books, and online articles. Finally key words and phrases are used to obtain public policy studies, case analyses, and law review articles.

\section{Discussion}

\subsection{Definition of Business Method}

Methods of doing business have traditionally been perceived to be something which should not be protected under patents. There has been some confusion, however, in the patent community over what constitutes a business method claim. "Business method" is a generic term that has been used by many to describe various types of process claims. While what constitutes a "business method patent" has not been clearly defined it can generally be described as a patent on a method for carrying out a particular business activity. Business method patents cover credit and loan processing, billings, houses, tax processing, investment and financial planning services, derivatives, valuation (financial instruments), advertising management, catalogue systems, coupon redemption (marketing), electronic auctions, shopping carts (ecommerce), human resource management, accounting, inventory monitoring, voting systems, gaming, gambling, and other miscellaneous day-to-day processes.(Chooi\& Ramakrishnan,2011).

\subsection{The Various Debates on Business Methods}

There are those who believe that software patents and business methods are among the tools used by non-practicing patent entities. (Love, 2013) There has been much criticism on the large number of patent lawsuits brought by such entities where the emphasis is on litigation instead of innovation.( President's Council of Economic Advisers,2013)For instances, In 2011, the US Congress enacted a temporary program that allowed the validity of business method patents to be challenged.(Pubic Law, 2011)Although there is some criticism on the granting of patents to protect certain software, protection for other software patents have been rejected.(Stuart, Graham \& Mowery, 2003)The debate continues on whether business methods should be patentable.

Most economists view the patent system as a necessary evil involving a tradeoff between access to a short term exclusive right to use an invention in return for the incentive to create the innovation and information about the innovation and how it works. Proponents state that without the patent system, there will be no incentive to innovate or create, and any such output would be kept secret to prevent misappropriation of the returns. (Mazzoleni and Nelson,1998) provide two more reasons for the patent system namely that it is an inducement for attracting needed investments to develop and commercialize inventions and to allow for the "orderly exploration of the broad prospects" that such novel inventions engender. The economic impacts of any increased application and use of patents to protect business methods provide a tradeoff between these benefits and the welfare cost for granting such monopoly right. Initially, a monopoly right may restrict competition but in the long run, competition may benefit if such a right allows for the entry of new and innovative firms. On the other hand, business methods innovations benefit from patent incentive although they may suffer if the 
patents restrict the combining and recombining of inventions to produce new products and processes.

According to some, it may be difficult to establish rules on patentability that distinguish between what are technological and tangible ideas, which would make them patentable, and those of a more abstract nature and thus not patentable.(Park, 2005) In this regard, two studies are worth mentioning. In 2000, based on a survey by Verkade, Visser and Bruining, it was noted that both large and small enterprises could benefit or suffer from software patent liberalization. In 2001, the Dutch Ministry of Economic Affairs reported that there was no definitive answer on issues of financial interest, the effects on competition, the value of patents for innovation or the incremental value of patent protection that would be achieved if used together with other means of legal protection. (Dutch Ministry of Economic Affairs, 2001)

Several recent studies(Hart, Holmes \& Reid, 2000) note that it is almost impossible to arrive at clear and concrete conclusions on the benefits of introducing software and business method patents, and that results of studies are consistent in showing up the diversity of opinions on this issue among software industry players. The debate can be divided between those for and those against business methods patents with both sides having equally valuable merits.

\subsubsection{Arguments in Favor of Business Methods}

As Justice Stone explains, "While a scientific truth, or the mathematical expression of it is not a patentable invention, a novel and useful structure created with the aid of knowledge of scientific truth may be". (Quinn, 2014)

Proponents of software patents question why software or business methods programs should be treated differently from other innovations arguing that there will be little incentive to invest in software innovations if the concepts and thinking behind them are not protected. They strongly urge patent protection as a means to promote innovation that will benefit all. (Note1)

In supporting business methods, (Likhovski, Spence \& Molineaux,2000)argue that the exclusion in law is unjust as such methods are economically advantageous in that they encourage innovation especially in areas that have not been fully explored or exploited. Other arguments on software patenting relate to material rewards for inventors which should be similar to those available to inventors in other fields.

Petersson's thesis states that ".....it is to be remembered that the mere fact that a business method patent has been issued does not necessarily mean that the patent will stand in a legal challenge. Of course, courts usually follow their earlier decisions, but it cannot be guaranteed that the court will follow the rules they set out in previous cases."(Petersson, 2002) Therefore, it will be acceptable if we have a look back to the laws about the business method patents and rewrite them for the benefit of the community of today. Petersson also is in favor of business method patents being treated similarly to other patent types as ultimately the objective is the same which is to secure material rewards for the inventor and to develop the economic market.

According to Grant E "...there are two reasons that are worth to be mentioned in support of the protection of patentability of business methods, first; the only viable alternative is secrecy, which may lead to stagnation, second, that protection is important for professional recognition and pride of authorship, and therefore it would help reduce industrial espionage.....' (Grant E, 2013).

Supra (Grant. E, 1979) suggests that any computer program that is submitted as a novel or unobvious method of manipulating electrical input signals (representing data) and transform the signals in pre specified manner to produce useful output signals should be amenable to patenting. Other commentators such as Samuelson (Samuelson, Davis, Kapor,\& Richman,1994)argues that computer software is such that it cannot be protected by either patent or copyright laws making it important to enact special software protection legislation for that purpose.

In addition, Duffy (Duffy, 2011) argues in order to be able to consider BMPs in U.S. Patent law, attentions should go to developments that have occurred outside the legal system. Duffy explains that in the last two decades of the twentieth century, as a result of growth of information technologies and availability of diverse empirical tools, there were tremendous significant changes in business methods patents, finance and management systems culminating in the deployment of scientific and mathematical methods to provide solutions for business methods and practices. As a result, it is prominent and necessary to pay precise attention to BMPs to take them into the business fields more than past. In addition, he argues that unlike traditional utility patents, BMPs are not the result of technical engineering, manufacturing or R\&D efforts although it can be said that some types of BMPs especially in the financial management field can be engineered. Arguing that in the last two decades of the 20th century, businesses have increasingly integrated scientific technologies and methods within their practices so as to blur the distinction between physicist and financier. (Moses $\mathrm{N}$. Muchiri, 2012). 


\subsubsection{Arguments Against Business Methods}

Criticisms against applying patents to business method programs and software revolve around the arguments that they discourage innovation, (Federal Trade Commission, 2003)have unclear boundaries, (Menell, 2007)and are of low quality. . (Allison \& Lemley,2007)A recent study showed that while BMPs are amongst the most litigated, claims against them are, in general, not valid as compared to claims made under other patent types. This suggests that BMPs use up disproportionate litigation resources while offering only marginal benefits.. (Allison, Lemley \& Walker, 2011).

Anti-BMP patent proponents believe that patent protection makes it possible for critical software components to be possessed by large organisations which can use them to stifle competition from innovative but less resource-endowed companies. To survive, such companies have to become profitable quickly and cannot afford the cost of obtaining patents or waiting years for their granting. It is also time-consuming and costly for them to establish if their idea hasn't already been patented. In any event they might not have the resources to defend themselves against claims of patent infringement even if they felt they had a strong case.(Note 2)

Lerner and Zhu. (Lerner\& Zhu, 2005) conducted a study of software patents to investigate the correlation between stronger patent protection and technological innovation. On the premise that poor quality patent reviews have created a huge growth in overlapping patent holdings, they report that both academics and practitioners believe that the granting of large number of property rights on small blocks of technology may be problematical for firms wishing to access key intellectual properties and dampens the incentive to innovate, which BMPs were among the most of them.(Martin, 2006).

Proponents for excluding such patents base their arguments on four arguments. (Likhovski, M. Spence, M. \& Molineaux, M., 2000). The first is that business methods are too abstract to form part of the law and patents will disturb the equilibrium between reward for innovation and the need for free competition because of the element of monopoly that patents involve. This might explain why items such as mortgage bonds, tracking stocks, and loyalty programs should not be patentable.

The second argument is the high social costs involved as all patents engender costs such as making products more expensive and deter competitors. It has also been argued that business methods result in higher costs than other patents and directly restrain competitors such as the imposition of multiple royalty fees. Since it is extremely difficult to establish the extent of such patent protection competition it may completely halt competition rather than aid it.

Thirdly, it is believed that patents are unnecessary as incentives for the development of business methods in general. Often any competitive advantage achieved from an improved business method would be enough to encourage incentives.

Finally, there is the question of whether patents actually contribute to improving overall social welfare. Even if patenting is not practiced, inventions could also occur though it might take time. Patenting may create some activity but its extent is questionable.

Lessig asserts that software development projects have become more costly due to business method and other software patents (Lessing, 2002) which place small businesses at a disadvantage as they impose additional legal expenses which most cannot afford.(Levine, 2001)

Both Lessig and Boyle note that business method patents are a major threat to the Internet and the public domain (James Boyle, L. Lessig, 2002) with the former predicting that the Internet will be severely affected by business method patents and expanded copyright protection. Lessig stating that business methods are a disaster and the biggest threat to innovation in cyberspace. As a result, according to him, the Internet will be controlled by big business in a way "that will disable once again the independent, unaffiliated, critical, questioning creativity that the Internet of the last ten years produced." (Lessig, 2000) Lessig also referred to business method patents as "new monster[s] called forth from an old statute" (Lessig, 2000) comparing those attempting to enforce them to the Mafiosiand calling for a suspension on their issuance. (Lessig, 2000) However, he may be mistaken, based on data available, when he states that business method patents are the clearest example of bad patents. Lessig has, however, also made the far more sensible statement that the major problem today is the federal government's role in over-protecting Intellectual Property generally. (Lessig, 1999).

Micheal et al., discuss the issue of patents as creating a monopoly that both inhibit and enhance innovation. The underlying matter is whether business methods contribute or detract from welfare. If they don't then patenting them would just be a waste of resources and create an unmotivated monopoly.(Likhovski et al, 2000).

Arguments opposing business method patentability are generally based on the president's commission on a tents which suggests that the laws be amended to ensure that computer programs would not be patentable on the following grounds:

1. "It is uncertain whether the statute permits a valid patent to be granted on computer programs;

2. Prior art cannot be searched because of the lack of classification technique and search files, and the large 
volume of prior art;

3. Program development has been adequate without patent protection; and

4. Copyright protection for programs is presently available." (Grant. E, 1979).

\section{Conclusion}

As can be seen, the nexus between patents, competition, and innovation is complex and may change over time and circumstances and among industries. (Hall, 2003).

The findings of this study show that there is much ambiguity surrounding the issue of granting patents to Business Methods with most arguments not supported by concrete evidence and data to justify either side's claims. This makes it difficult to verify and support the arguments put forward both by those for and against such patenting. This is because there is no accepted methodology to evaluate business methods and their impact on the social welfare. Also, the parties involved are still uncertain about what fosters the innovative spirit and how patents impact the creative or inventing process..(Likhovski, 2000)There is no certain method that points in one direction or another in terms of whether patents aid or hinder inventions and innovation and which issues should be prioritized over others.

There should be concerted attempts to overcome this conundrum especially with the high stakes involved as the impact of technology on humans life is extremely pervasive and require a comprehensive and systematic approach to address the issues surrounding patenting. The lack of proper guidelines causes much confusion among inventors, commentators, and even the courts, and such a situation does not contribute to the promotion and advancement in technological and economic fields.

Guidelinesthat are uniform and applicable to all nations and judicial systems are needed to overcome this difficulty. A first step would be for the relevant parties to discuss and collaborate to address the issue of Business Method Programs and the lack of harmonized laws and find ways to overcome the various difficulties involved to ensure that jurisdictional issues move in tandem with the developments in internet technology. Among the issue that should be addressed is the protection of inventors' rights as well as the invention itself.

There has been much interest among researchers on examining the existing difficulties and evaluating the efficacy of current legislation with the number of studies almost doubling over the past few years. However, there is still a need to study options that point the way towards solutions as well as to examine the extent of these proposed options in resolving computer program and business method patent issues.

Future research should concentrate on providing greater clarity in the various laws and acts that are cited by judges and how the approaches taken will lead to a more coherent and systematic way of protecting Business Method Programs. Also it should address the lack of data on the way the patent system works in practice and how judges justify their reasons for their decisions which currently are based on their individual understanding of the patenting laws or how the patent lawsuits will be drafted rather than the overarching implications of their effect on the innovation and creation process.

\section{References}

Allison, J. R. \& Mann, R. J. (2007). Disputed Quality Of Software Patents, WASH. U. L. REV, 85, 297.

Allison, J. R., Lemley, M. A. \& Walker J. (2011). Patent Quality and Settlement Among Repeat Patent Litigants, GEO. L.J. (99) 677, 707-08.

Boyle, J. Lessig, L. (2002), 'Future of ideas Daedalus, fencing off ideas: enclosure \& the disappearance of the public domain, 13.

Chooi, Y. W. , Ramakrishnan G., (2011), Business Method Patents http://www.google.com/url?sa=t\&rct=j\&q=\&esrc=s\&source= web\&cd=2\&cad=rja\&uact=8\&ved=0CCkQFjAB\&url=http\%3A\%2F\%2Fwww.rodyk.com\%2Fusermedia\%2Fdocuments\%2FRodyk Reporter_Mar11.pdf\&ei=bcqUVdm1EsWKuASkZfwCA\&usg=AFQjCNF9gCl2bUH9xiS5wPaPtKoxp1T8HQ\&sig2=EsJXtgBIR2NKupF̄bvYBvw\&bvm=bv.96952980,d.c2E (July 2, 2015).

Duffy, J. F. (2011), Why Business Method Patents?, Stanford Journal Law Review, (63)9, 247-288.

Durell, K.L. (2000), Intellectual Property Protection for Computer Software: How Much and What Form is Effective?, International Journal of Law \& Information Technology, 2-8.

Dutch Ministry of Economic Affairs (2001), p 70.

Federal Trade Commission, (2003). To Promote Innovation: The Proper Balance Of Competition And Patent Law And Policy(56).Http://Www.Ftc.Gov/Os/2003/10/Innovationrpt.Pdf.

Grant, M. E. (1979). Protecting Proprietary Rights of Computer Programs: The Need for New Legislative Protection, CATH. U. L. REV, (21),181-200.

http://heinonline.org/HOL/Page?handle=hein.journals/cathu21\&div=18\&collection=journals\&set_as_cursor=0\&men_tab=srchresul ts\&terms=\%28patentability\%20AND\%20of\%20AND\%20computer\%20AND\%20program\%29\&type=matchall\#195 .(October 13 , 
2013).

Hall, B.H., (2003), University of California at Berkeley and NBER. Paper prepared for the Atlanta Federal Reserve Bank Conference on Business Method Patents, Sea Island, Georgia, 3-5.

Hart, R. Holmes, P. \& Reid, J.(2000), The Economic Impact of Patentability of Computer Programs. http://europa.eu.int/comm/internal_market/en/indprop/study.pdf. (November 27, 2013).

Hutter,H. Riter. B. \&Jian, W. (2009) The Hows and Whys of Software Patent Protection http://www.iammagazine.com/issues/article. ashx?g=79351366-694a-40ad-85a3-8eee119db51a (September 28, 2012).

Leahy-Smith America Invents Act, Pub.L. No. 112-29, § 18, 125 Stat. 284, 329-31 (2011).

Lerner, J. \& Zhu, F. (2005), What is the impact of software patent shifts? Evidence from Lotus v. Borland: NBER Working Paper No. 11168.

Lessig, L. (1999), The Problem With Patents, Industry Standard, http://www.thestandard.com/article/display/0,1151,4296,00.html

Lessig, L. (2000), Industry Standard, Patent Problems, http://www.wideopen.com/thestandard/425.html.

Lessig, L. (2000), The Death of Cyberspace, Wash \& Lee L. Rev,(57), 337, 345-47.

Lessig, L. (2002). Multinational Monitor Controlling The 'Net: How Vested Interests Are Enclosing The Cyber Commons And Undermining Internet Freedom, [March 1, 2002].

Lessig,L.(2000), Online Patents: Leave Them Pending, Wall St. J, http://reason.com/0206/fe.jw.cyberspaces.shtml.

Levine, D. S. (2001). Times One on One with Lawrence Lessig, San Fran. Bus. (30), http://sanfrancisco.bizjournals.com/sanfrancisco/stories/2001/12/03/newscolumn10.html.

Likhovski, M. Spence, M. \&Molineaux, M.(2000). The First Mover Monopoly, a study on patenting business methods in Europe, Oxford Intellectual Property Research Centre, St Peter's College, Oxford University, pp 4,7, 30,45.

Love, B. J. (2013), An Empirical Study of Patent Litigation Timing: Could a Patent Term Reduction Decimate Trolls Without Harming Innovators?,U. PA. L. REV, 161,pp1309-1343.

Martin, N. L. (2006), The Strategic Value of Business Method Patents in Information Systems,(Ph.D thesis), Southern Illinois University at Carbondale, $p 93$.

Menell. P. S. A, (2007), Method for Reforming the Patent System, Mich. Telecomm.\& Tech. L. REV., (13)pp 487, 505-06. ("The boundaries of software and business method patents are inherently ambiguous.").

Muchiri, M.N. (2012). Business Method Patents Revisited: Recent Developments in the Protection of Computer Implemented Business Methods in the U.S.-Between the Promotion of Innovation and Protection of Investments?,p 44.http://ssin.com/abstract=2171724.

Park, J. (2005), Has Patentable Subject Matter Been Expanded?--A Comparative Study on Software Patent Practices in the European Patent Office, the United States Patent and Trademark Office and the Japanese Patent Office, p 336.

Petersson, J. (2001-2002). Business Method Patents, (Master thesis), Faculty of Law Handelshögskolan, University of Gothenburg, $p$ 29.

President's Council of Economic Advisers, the National Economic Council, and the Office of Science \& Technology Policy, Patent Assertion and U.S. Innovation (2013) 5 http://www.whitehouse.gov/sites/default/files/docs/patent_report.pdf.

Pub.L. No. 112-29, § 18, 125 Stat. 284, 329-31 (2011).

Quinn, G. (2014). The History of Software Patents in the United States, http://www.ipwatchdog.com/2014/11/30/the-history-of-softwarepatents-in-the-united-states/id=52256/ (December 15, 2014).

Samuelson, P. Davis, R. Kapor, M. D. \& Richman, J.H. (1994), A Manifesto Concerning The Legal Protection Of Computer Programs. Colum Law Review94 (2308), 135.

Stuart, J. Graham, H. \& Mowery, D. C. (2003), Intellectual Property Protection in the U.S. Software Industry, in Patents In The Knowledge-Based Economy, pp 219-232.

Thiele, A. R., Blakeway, J. R. \&Hosch, Ch. M.(2010), The Patent Infringement Litigation Handbook: Avoidance and Management, ABA Publisher, p 8.

\section{Notes}

Note1. Software \& Business Method Patents, http://www.lewissilkin.com/Knowledge/2011/October/ /media/Knowledge \%20PDFs/MBT/An\%20introduction\%20to\%20software\%20and\%20business\%20method\%20patents.ashx.(February 2014).

Note2. Software \& Business Method Patents, http://www.lewissilkin.com/Knowledge/2011/October/ /media/Knowledge \%20PDFs/MBT/An\%20introduction\%20to\%20software\%20and\%20business\%20method\%20patents.ashx (February 2014). 